\title{
Pyrazolium-sulfonates. Mesomeric betaines possessing iminium-sulfonate partial structures
}

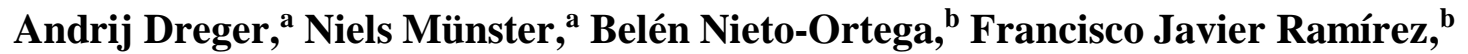 \\ Mimoza Gjikaj, ${ }^{c}$ and Andreas Schmidt ${ }^{\mathrm{a} *}$ \\ ${ }^{a}$ Clausthal University of Technology, Institute of Organic Chemistry, Leibnizstraße 6, \\ D-38678 Clausthal-Zellerfeld, Germany \\ ${ }^{b}$ University of Málaga, Departamento de Química Física, Facultad de Ciencias, \\ 29071 Málaga, Spain \\ ${ }^{c}$ Clausthal University of Technology, Institute of Inorganic Chemistry, Paul-Ernst-Straße 4, \\ D-Clausthal-Zellerfeld, Germany \\ E-mail: schmidt@ioc.tu-clausthal.de
}

Submitted in honor of the $60^{\text {th }}$ birthday of Professor Rainer Beckert

DOI: $\underline{\text { http://dx.doi.org/10.3998/ark.5550190.0013.303 }}$

\begin{abstract}
Pyrazolium-3-sulfonates and pyrazolium-4-sulfonates possessing the iminiomethanesulfonate and the 3-iminio-pro-1-ene-2-sulfonate partial structure are prepared. Formally, they represent sulfur analogs of cross-conjugated (CCMB) and pseudo-cross-conjugated heterocyclic mesomeric betaines (PCCMB) and sulfur trioxide adducts of abnormal $N$-heterocyclic carbenes ( $a \mathrm{NHC}$ ) and $N$-heterocyclic carbenes (NHC), respectively. The theoretical as well as experimental vibrational spectra of these two classes are compared. Results of calculations of HOMO/LUMO profiles and an X-ray single crystal structure analysis are presented.
\end{abstract}

Keywords: $N$-Heterocyclic carbene, IR spectroscopy, pyrazol-3-ylidene, pyrazol-4-ylidene, $\mathrm{SO}_{3}$ adducts

\section{Introduction}

The iminiomethanesulfonate group I and the 3-iminio-prop-1-ene-2-sulfonate group II (Figure 1) are partial structures of hitherto almost overlooked classes of heterocyclic mesomeric betaines. Formally, they represent sulfurtrioxide adducts of $N$-heterocyclic carbenes (NHC), remote $N$ - 
heterocyclic carbenes ( $r \mathrm{NHC}$ ), or abnormal $N$-heterocyclic carbenes ( $a \mathrm{NHC}$ ), respectively, which possess the partial structures III and IV in heterocyclic rings. ${ }^{1}$<smiles>CC(=[N+](C)C)S(=O)(=O)[O-]</smiles>

I

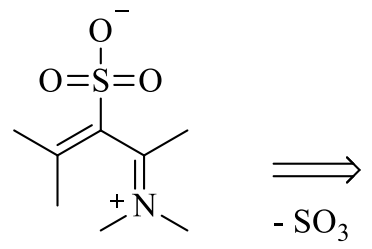

II

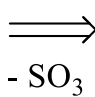

$-\mathrm{SO}_{3}$

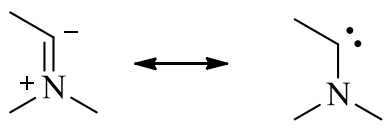

III

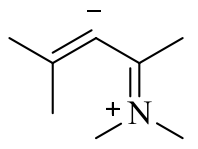

IV

Figure 1. Iminium-sulfonates $\mathbf{I}$ and $\mathbf{I I}$ as formal $\mathrm{SO}_{3}$ adducts of $N$-heterocyclic carbenes.

Figure 2 shows $N$-heterocyclic carbenes of imidazole and pyrazole. Imidazol-2-ylidene is an NHC, whereas imidazol-4-ylidene - which cannot be represented by an electron sextet structure is a member of the class of $a \mathrm{NHC}^{2}$ Pyrazol-3-ylidene has been isolated as metal complexes, ${ }^{3}$ trapped with heterocumulenes, ${ }^{4}$ examined mass-spectrometrically, ${ }^{5}$ and rearranged to 4aminoquinolines. ${ }^{6}$ It belongs to the class of NHCs whereas its isomer, pyrazol-4-ylidene has been described as remote $N$-heterocyclic carbene, ${ }^{7}$ cyclic allene ${ }^{8}$ or aromatic zwitterion. ${ }^{9}$ The correct representation of this structure has been discussed controversely. ${ }^{10}$

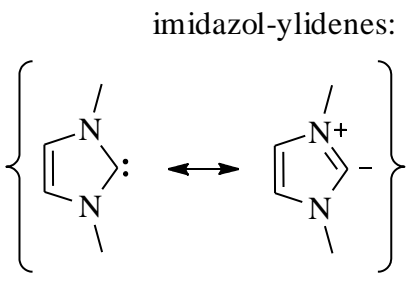

NHC

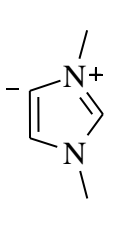

aNHC

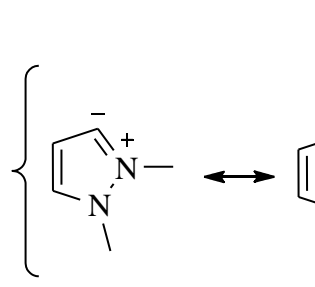

$\mathrm{NHC}$

pyrazol-ylidenes:

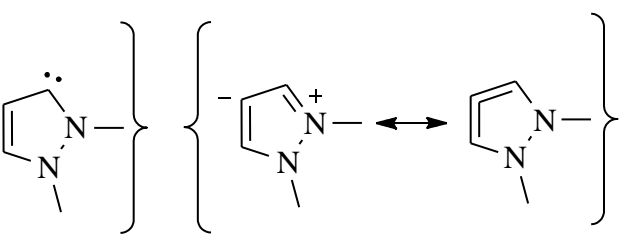

rNHC

Figure 2. Distinct types of $N$-heterocyclic carbenes.

The carbon dioxide analogs of the sulfonates presented here are well known in heterocyclic as well as $N$-heterocyclic carbene chemistry. Thus, the partial structure $\mathbf{V}$ (Figure 3 ) can be identified in pseudo-cross-conjugated mesomeric betaines (PCCMB) ${ }^{11}$ such as pyrazolium-3carboxylates, imidazolium-2-carboxylates, and 1-methylpyridinium-2-carboxylates which are indeed precursors of $\mathrm{N}$-heterocyclic carbenes. ${ }^{12}$ They are formed on cleavage of the union bond 
between positive and negative portions of the molecule. Partial structure VI is characteristic for cross-conjugated mesomeric betaines (CCMB) such as pyrazolium-4-carboxylates, imidazolium4-carboxylates, and 1-methylpyridinium-3-carboxylates which are more stable toward decarboxylations than PCCMBs. ${ }^{13}$ However, it was shown that imidazol-4-ylidenes, formed in situ from imidazolium-4-carboxylates, can be trapped with isocyanates. ${ }^{13}$

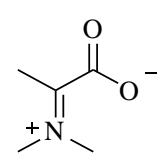

V

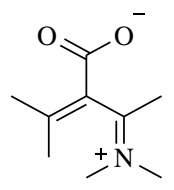

VI
PCCMB:

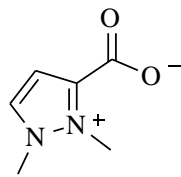

CCMB :

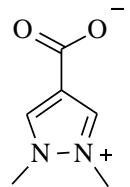

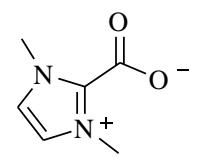
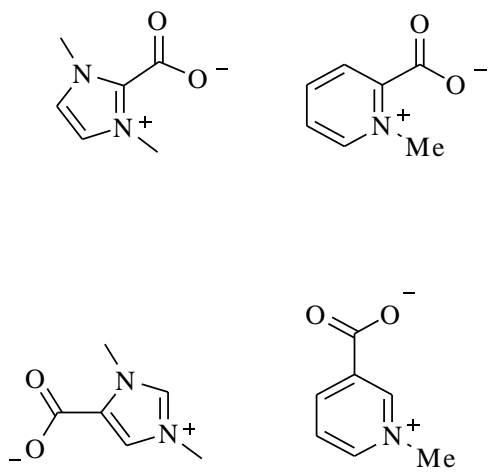

Figure 3. Iminium-carboxylates and mesomeric betaines derived thereof.

Some examples of iminium-sulfonates have been described in the literature. Thus, N, $\mathrm{N}^{\prime}-$ dimethylaminoiminiummethane sulfonate $\mathbf{3}$ is a representative of an open-chain molecule with partial structure I (Figure 1). It has been identified as metabolite of the biologically active thiocarbamide dimethylthiourea $\mathbf{1}$, and it is formed via the corresponding sulfenic and sulfinic acids before it is converted into sulfate and dimethylurea. X-ray analyses prove the formation of zwitterionic forms in the solid state, similar to the isomeric $N, N$-dimethyl derivative. ${ }^{14}$ Thus, in 2 the negative charge is delocalized in the pyramidal O-S-O group. Three-center four-electron $\pi$ interactions of the two filled $\mathrm{p}_{\pi}$ orbitals of the nitrogen atoms and a vacant carbon $\mathrm{p}_{\pi}$ orbital explain the very short C-N bonds of $130.3(3) \mathrm{pm}$ and $130.4(3) \mathrm{pm}$. The C-S bond is nearly 10 pm longer than expected [188.8(2) pm], when the sum of the covalent radii of $\mathrm{C}$ and $\mathrm{S}$ is taken into consideration $[179 \mathrm{pm}] .{ }^{15}$ The sulfonate $\mathbf{3}$ is much more stable than the sulfinate 2 . Similarly, the $\mathrm{C}_{\mathrm{sp}}{ }^{2}-\mathrm{N}$ bonds are shortened. The $\mathrm{S}-\mathrm{O}$ bonds of the sulfonate group are nearly equivalent, and the C-S bond is shorter than that of 2 [182.0(3) pm], but longer than a normal CS bond. ${ }^{16}$

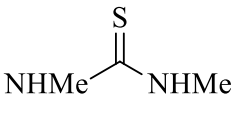

1

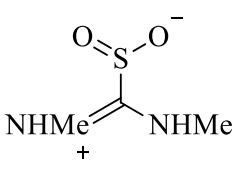

2

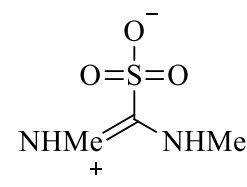

3

Scheme 1. Open-chain iminium-sulfinate 2 and -sulfonate 3. 
Imidazolium-2-sulfonate 7 is an example of a cyclic mesomeric betaine possessing partial structure I (Scheme 2). Seemingly, this compound cannot be formed by reaction of imidazol-2ylidene 5 with $\mathrm{SO}_{3}$ due to reduction of the sulfur atom. ${ }^{17}$ It was prepared by reaction of imidazol2-ylidene 5 with sulfurylchloride to 2-chloroimidazolium 6 which was then treated with aqueous potassium cyanide to give the betaine 7 as colorless crystals. ${ }^{18}$ The C-S bond distance in 7 was determined by X-ray crystallography to be 182.2(2) pm. Protonation can be accomplished with $\mathrm{HBF}_{4}$ diethyletherate and $\mathrm{HF} / \mathrm{SbF}_{5}$, respectively. ${ }^{19}$

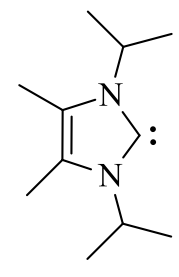

5

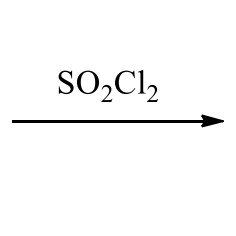

6

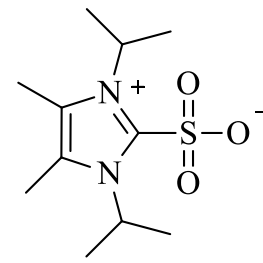

7

Scheme 2. Synthesis of imidazolium-2-sulfonate.

Benzimidazolium-2-sulfonates $\mathbf{8}$ have been obtained on reaction of the corresponding thiones with $\mathrm{MeNCl}_{2}$ and subsequent oxidation with $\mathrm{HClO}_{4},{ }^{20}$ or starting from benzimidazoline2-ones and $\mathrm{POCl}_{3}$ and subsequent treatment with sulfites or bisulfites ${ }^{21}$ (Scheme 3). Some derivatives have been described as dyes. ${ }^{22}$ As oxidation of benzimidazoline-2-thiones with hydroperoxide resulted in the formation of benzimidazolium sulfate, the intermediate formation of benzimidazolium-2-ylidene was proposed which is trapped by protons. ${ }^{23}$ Indazolium-3sulfonates 9 played a role in dye chemistry. ${ }^{24}$ Pyridinium-2-sulfonates $\mathbf{1 0}$ have been used as fluorescent probes for DNA labeling, ${ }^{25}$ polymers, ${ }^{26}$ and antibiotics. ${ }^{27}$ They were also used in polymer synthesis ${ }^{28}$ and dye chemistry. ${ }^{29} \mathrm{~N}$-Fluoropyridinium-2-sulfonates are known to be highly selective fluorinating agents. ${ }^{30}$ The compounds $\mathbf{1 1}^{31}$ and $\mathbf{1 2}$ have partial structure II. $\mathrm{N}$ Methylpyridinium-3-sulfonate $\mathbf{1 2}$ has been isolated from gorgonian octocorals found in the Caribbean $\mathrm{Sea}^{32}$ and has been employed in a continuous flow process. ${ }^{33}$ Pyridinium-3-sulfonate is by far the most common building block of more complex structures ${ }^{34}$ including dyes. ${ }^{35}$ To the best of our knowledge, no example of a five-membered representative has been described to date. The salt pyrazolo[1,2-a]pyrazolium-6-sulfonic acid, however, is mentioned in the literature. $^{36}$<smiles>[R]n1c(S(=O)(=O)O)[n+]([R])c2ccccc21</smiles>

8

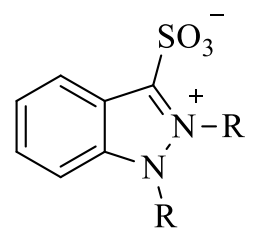

9

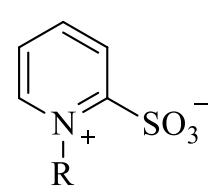

10<smiles>CS(=O)(=O)C(=C(c1ccccc1)[N+]1=C2CCCN2CCC1)c1ccccc1</smiles>

11<smiles>C[n+]1cccc(S(=O)(=O)[O-])c1</smiles>

12

Scheme 3. Sulfonates possessing partial structures I and II. 
In continuation of our work in mesomeric betaine chemistry, ${ }^{37} \mathrm{~N}$-heterocyclic carbenes in heterocyclic synthesis ${ }^{38}$ and catalysis, ${ }^{39}$ and vibrational spectroscopy for the characterization of these classes of compounds ${ }^{40}$ we wish to report here the syntheses and characterizations of pyrazolium-3-sulfonates and pyrazolium-4-sulfonates. We performed X-ray crystallography, vibrational spectroscopy, and calculations to characterize these new mesomeric betaines.

\section{Results and Discussion}

\section{Syntheses}

The thiones 14a,b were prepared starting from the mesomeric betaines 13a,b via the $N$ heterocyclic carbenes 13A. 2,5-dimethyl-1-phenylpyrazolium-3-sulfonate 15a was then synthesized according to a modified literature procedure ${ }^{41}$ from thione 14a with chlorine in water as colorless water-soluble solid in $51 \%$ yield. Likewise, the 3,5-dichloro derivative $\mathbf{1 5 b}$ has been obtained in $80 \%$ yield.<smiles>[X]c1cc([X])cc(-n2c(C)cc(C(=O)[O-])[n+]2C)c1</smiles>

13a: $\mathrm{R}=\mathrm{H}$ 13b: $\mathrm{R}=\mathrm{Cl}$<smiles>[X]c1cc([X])cc(-n2c(C)cc(S(=O)(=O)O)[n+]2C)c1</smiles>

$15 \mathbf{a}(51 \%)$ $15 \mathbf{b}(80 \%)$<smiles>[X]c1cc([X])cc(-n2c(C)cc(C)[n+]2C)c1</smiles>

13A<smiles>[X]c1cc([X])cc(-n2c(C)cc(=S)n2C)c1</smiles>

$14 \mathbf{a}, \mathbf{b}$

Scheme 4. Synthesis of pyrazolium-3-sulfonates via $N$-heterocyclic carbenes of pyrazole.

Several effective sulfonations of pyrazoles in position 4 under relatively mild conditions have been described, among them procedures employing a mixture of acetic anhydride and $96 \%$ sulphuric acid. ${ }^{42}$ Oleum $\left(20 \% \mathrm{SO}_{3}\right)^{43}$ and chlorosulfonic acid in chloroform ${ }^{44}$ are also known sulfonating reagents for pyrazoles. Sulfonation of 5-methyl-1-phenylpyrazole 16a was accomplished in $73 \%$ yield using concentrated sulfuric acid, and in almost quantitative yield 
using chlorosulfonic acid. 5-Methyl-1-phenylpyrazole-4-sulfonic acid $\mathbf{1 7}$ was obtained as slightly brownish, water-soluble solid. Methylation of $\mathbf{1 7}$ and subsequent saponification of the resulting methylsulfonate resulted in the formation of 2,5-dimethyl-1-phenylpyrazolium-4sulfonate 18a in $46 \%$ yield over two steps.

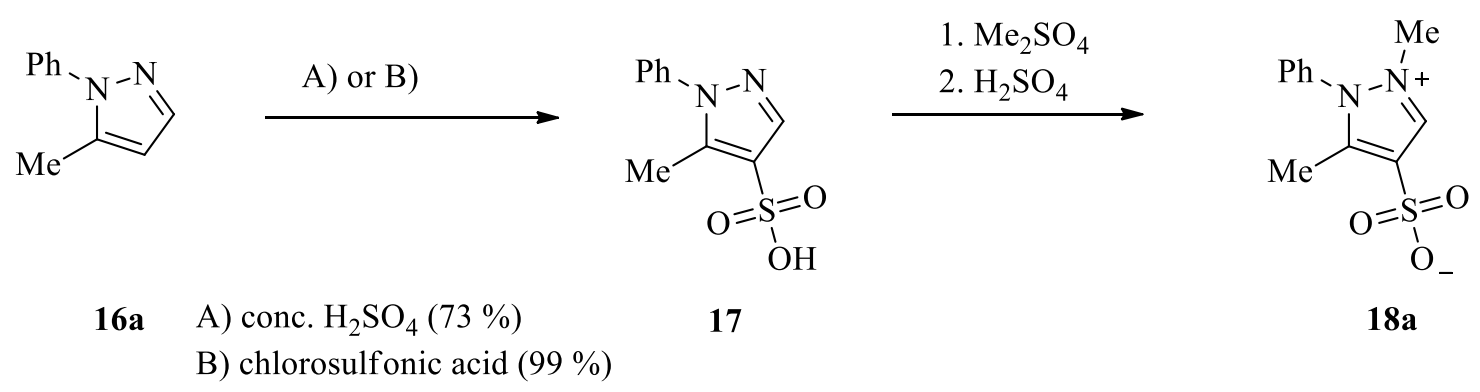

Scheme 5. Synthesis of pyrazolium-4-sulfonates.

Pyrazoles, which are unsubstituted in position 4, can also be converted into pyrazolium-4sulfonates on treatment with dialkylsulfates. The yields, however, are quite low and strongly depend on the concentration of the dialkylsulfate. Thus, reaction of 5-methyl-1-phenylpyrazole 16a with one equivalent of dimethylsulfate gave $12 \%$ yield of the pyrazolium-4-sulfonate 18a, whereas ten equivalents gave $41 \%$ yield. Reaction of 3,5-dimethyl-1-phenylpyrazole $\mathbf{1 6 b}$ gave only $19 \%$ of the corresponding pyrazolium-sulfonate $\mathbf{1 8 b}$. Correspondingly, sulfonations of the pyrazoles 16c,d were accomplished. Pyrazolium methylsulfates 19 were obtained as by-products in all reactions.

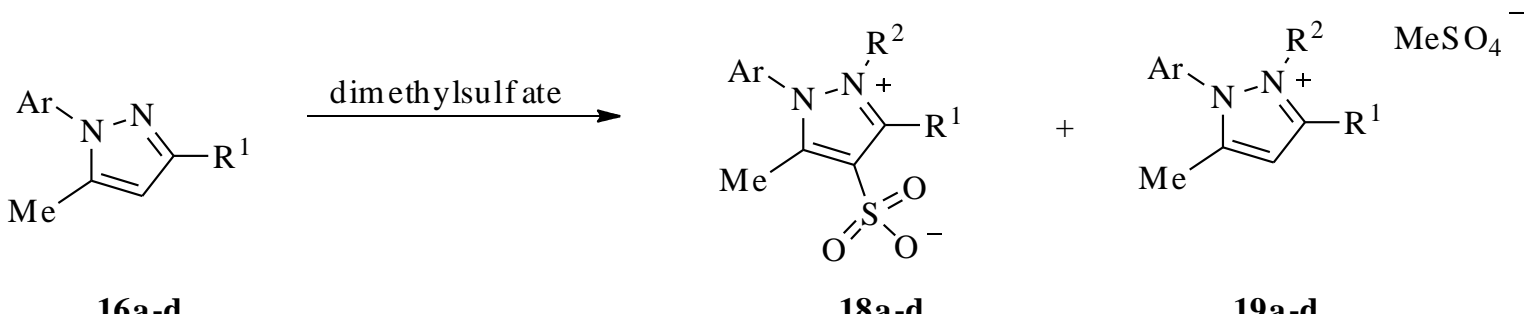

16 a-d
a: $\mathrm{R}^{1}=\mathrm{H}, \mathrm{R}^{2}=\mathrm{Me}, \mathrm{Ar}=\mathrm{Ph}(41 \%)$
b: $\mathrm{R}^{1}=\mathrm{R}^{2}=\mathrm{Me}, \mathrm{Ar}=\mathrm{Ph}(19 \%)$
c: $\mathrm{R}^{1}=\mathrm{H}, \mathrm{R}^{2}=\mathrm{Et}, \mathrm{Ar}=\mathrm{Ph}(14 \%)$
$\mathrm{d}: \mathrm{R}^{1}=\mathrm{H}, \mathrm{R}^{2}=\mathrm{Me}, \mathrm{Ar}=3,5$-dichlorophenyl $(20 \%)$

Scheme 6. Synthesis of pyrazolium-4-sulfonates by dimethylsulfate.

Heating a sample of 2,5-dimethyl-1-phenylpyrazolium methylsulfate 19a in concentrated sulfuric acid gave the corresponding sulfonate 18a in $17 \%$ yield. 


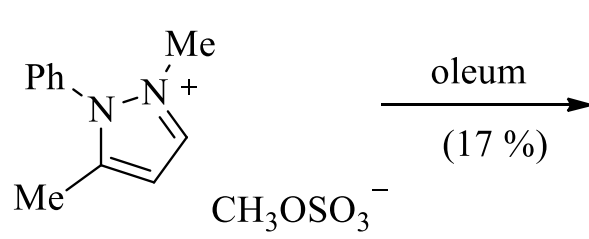

$19 a$

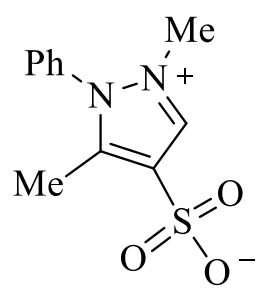

$18 \mathbf{a}$

Scheme 7. Sulfonation of a pyrazolium salt.

The structure of betaine $\mathbf{1 8 d}$ was confirmed by a single crystal X-ray analysis. Single crystals were obtained by slow evaporation of a saturated solution in methanol. The molecule crystallizes with one molecule of methanol. The C-S bond length was determined to be $177.1 \mathrm{pm}$, which is slightly shorter than the sum of the covalent radii of $\mathrm{C}$ and $\mathrm{S}[179 \mathrm{pm}],{ }^{2}$ and considerably shorter than in the compounds mentioned above. The $N$-N bond length of pyrazole was found to be 137.3 $\mathrm{pm}$. The phenyl ring is adopts a torsion angle of $-65.94(4)^{\circ}$ about the $\mathrm{C}-\mathrm{N}$ bond.

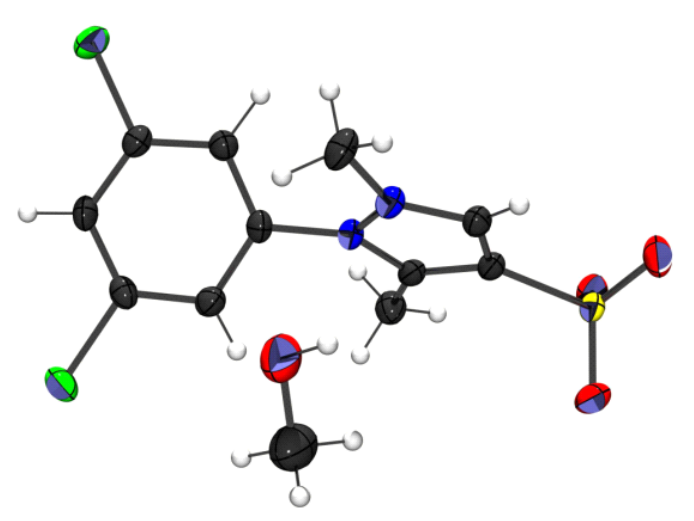

Figure 4. X-ray single crystal analysis of pyrazolium-sulfonate 18d.

\section{Classifications}

Mesomeric betaines are defined as conjugated molecules which can exclusively be represented by dipolar canonical formulae which delocalize the positive as well as negative charge within a common $\pi$-electron system. ${ }^{11 a}$ A closer inspection of the canonical formulae of pyrazolium-3sulfonates and pyrazolium-4-sulfonates shows differences with respect to the delocalization of the charges. Thus, in pyrazolium-3-sulfonates common atoms for either charge exist, when electron sextet structures are formulated as shown. In this case, the positive charge is formally localized on the oxygen atoms of the sulfonate group. This mesomeric structure, although without any physical consequence, is characteristic of pseudo-cross-conjugated mesomeric betaines (PCCMB). In 
addition, the characteristic dipole of PCCMBs can be dissected from the mesomeric structures. ${ }^{11 a}$

Mesomeric structures

Characteristic dipole type
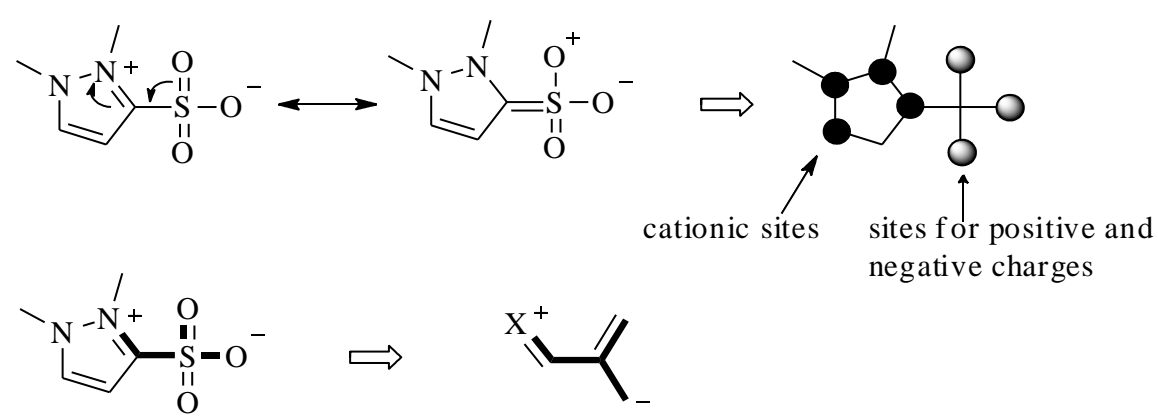

Figure 5. Identification of pseudo-cross-conjugated mesomeric betaines.

By contrast, according to the mesomeric structures in pyrazolium-4-sulfonates the charges are strictly delocalized in separated parts of the molecule. ${ }^{11 a}$ The characteristic dipole type of cross-conjugated heterocyclic mesomeric betaines (CCMB) can be dissected from the canonical formulae.

Mesomeric structures

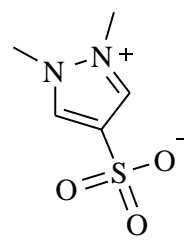

Characteristic dipole type
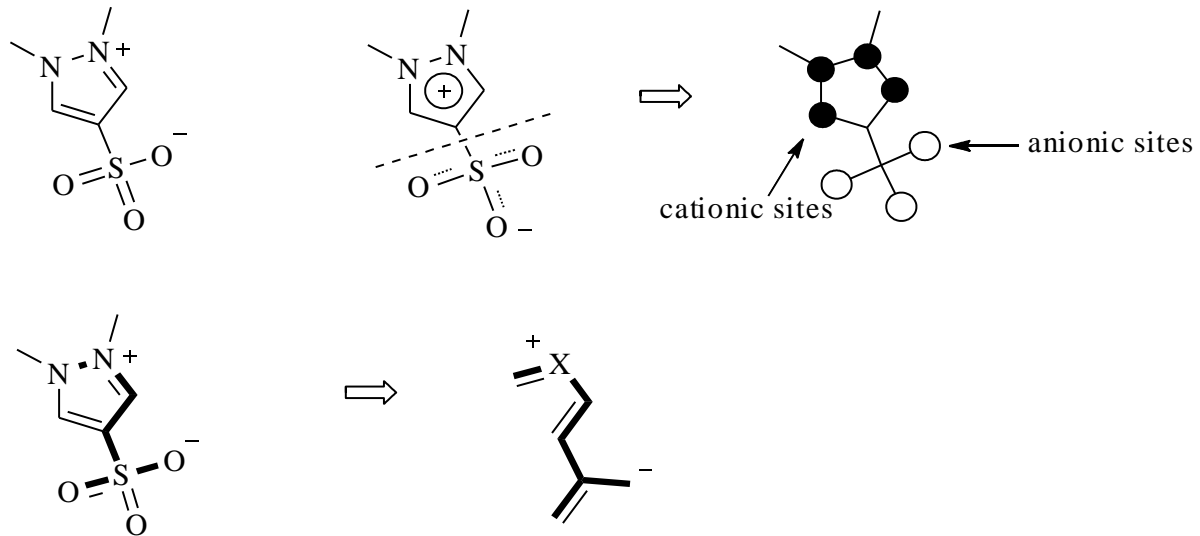

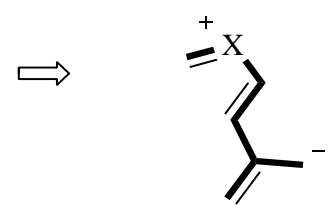

Figure 6. Identification of cross-conjugated mesomeric betaines.

To compare the two types of mesomeric betaines mass spectrometrically, we sprayed samples of 15a and 18a from methanol and observed base peaks at $\mathrm{m} / z=275.0$ and additional peaks at 253.1 in the ESI mass spectra at $0 \mathrm{~V}$ fragmentor voltage. These peaks can be assigned to the pyrazolium-sulfonates plus $\mathrm{Na}^{+}$and $\mathrm{H}^{+}$, respectively. For the case of $\mathbf{1 8 a}$, at $100 \mathrm{~V}$ fragmentor voltage the pyrazolium cation, formed by loss of $\mathrm{SO}_{3}$ from 18a and trapping of the resulting pyrazol-4-ylidene by a proton, gives the base peak at $m / z=173.1$.

The HOMO/LUMO profiles of the two pyrazolium sulfonates are displayed in Fig. 7. They show that the sulfur atom is always a nodal position of the HOMOs, whereas the LUMOs are essentially located in the cationic moieties. However, a subtle difference is seen: the LUMO in pyrazolium-3-sulfonate is somewhat extended over the sulfonate group and more specifically 
over the C-S bond (here the union bond). This result is related with the ability of the positive and negative charges to delocalize on the sulfonate group, as aforementioned, which is characteristic of PCCMB.
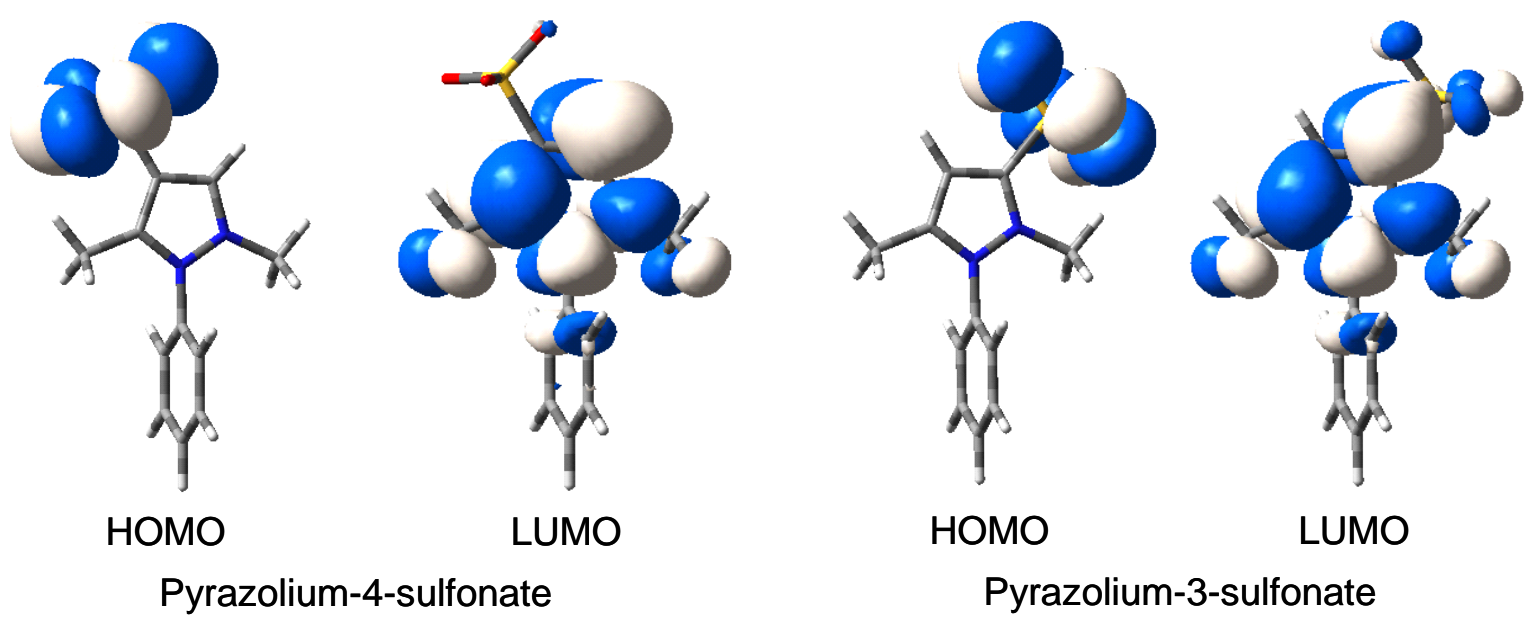

Figure 7. HOMO/LUMO of pyrazolium-3-sulfonate 15a and pyrazolium-4-sulfonate 18a.

We also calculated the electrostatic surface potentials of the two types of sulfonates, which are shown in Fig. 8 together with the permanent dipole moments for the ground state.
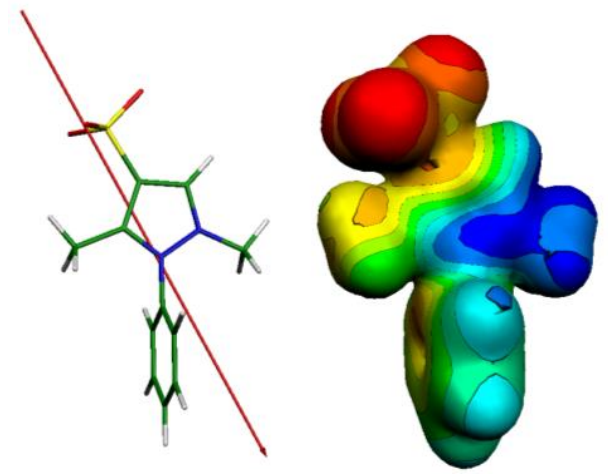

$\mu=23.62 \mathrm{D}$ Pyrazolium-4-sulfonate
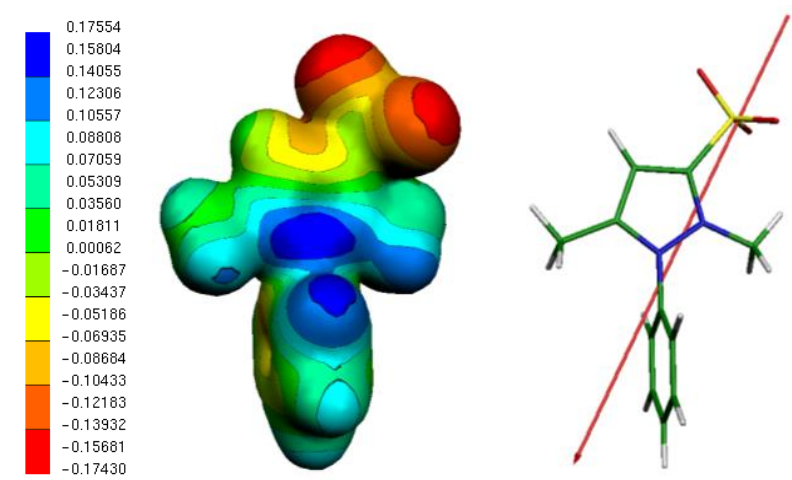

Pyrazolium-3-sulfonate $\mu=20.51 \mathrm{D}$

Figure 8. Electrostatic surface potential and permanent dipole moment of pyrazolium-3sulfonate 15a and pyrazolium-4-sulfonate 18a, respectively.

As is observed, the change in the sulfonate position, from 15a (PCCMB) to 18a (CCMB), gives rise to a $15 \%$ of dipole moment increase, namely from 20.51 to $23.62 \mathrm{D}$. This fact is accompanied by a relocation of the electric charge. Thus, the partial charge over the sulfonate groups changes from -0.535 (PCCMB) to -0.545 a.u. (CCMB), while that located on the pyrazolium moiety goes from +0.915 to +0.946 a.u. respectively. Interestingly, the positive 
charge specifically hosted over the five atoms of the pyrazolium skeleton grows up more than for the whole moiety, namely from +0.599 to +0.773 a.u. This is largely caused by a general increase of the positive charge on all the atoms except the sulfur-attached carbon, whose negative charge is dramatically increased, namely from -0.375 to -1.110 a.u. on going from 3sulfonate to 4-sulfonate.

The optimized bond lengths and calculated stretching force constants of the more relevant bonds are presented in Table 1. The calculated distance for the union bond, C-S, is greater in 3sulfonate than in 4-sulfonate. We would like to emphasize how the force constants are more sensitive than the bond lengths to the cross conjugation phenomenon. Taking the C-S stretching vibration as reference, the relative variation of its force constant is noticeably higher $(8.9 \%)$ than the optimized bond lengths $(1.1 \%)$. This fact allows us to detect a subtle difference in the S-O bonds of these molecules, whose averaged force constants are 8.74 and $8.42 \mathrm{mdyn} / \AA$, respectively, while similar bond lengths are predicted. The rest of bonds exhibits very low deviations, being always more relevant the variations in force constant than in bond distances.

Table 1. B3pw91/6-311+G(2d,p) optimized distances and calculated stretching force constants for relevant bonds of pyrazolium sulfonates

\begin{tabular}{ccccc}
\hline & \multicolumn{2}{c}{ Pyrazolium-4-sulfonate 18a } & \multicolumn{2}{c}{ Pyrazolium-3-sulfonate 15a } \\
Bond & Length $(\AA)$ & Force const. & Length $(\AA)$ & Force const. \\
\hline $\mathrm{N}_{1}-\mathrm{N}_{2}$ & 1.360 & 6.61 & 1.362 & 6.58 \\
$\mathrm{~N}_{2}-\mathrm{C}_{3}$ & 1.332 & 10.59 & 1.337 & 10.39 \\
$\mathrm{C}_{3}-\mathrm{C}_{4}$ & 1.384 & 7.20 & 1.386 & 7.12 \\
$\mathrm{C}_{4}-\mathrm{C}_{5}$ & 1.392 & 9.52 & 1.387 & 9.71 \\
$\mathrm{C}_{5}-\mathrm{N}_{1}$ & 1.349 & 7.41 & 1.349 & 7.45 \\
$\mathrm{~N}_{1}-\mathrm{C}_{6}$ & 1.434 & 5.28 & 1.433 & 5.30 \\
$\mathrm{~N}_{2}-\mathrm{C}_{7}$ & 1.452 & 5.04 & 1.452 & 5.01 \\
$\mathbf{C}_{4}-\mathrm{S}_{8} / \mathbf{C}_{3}-\mathbf{S}_{8}$ & $\mathbf{1 . 7 8 4}$ & $\mathbf{3 . 1 7}$ & $\mathbf{1 . 8 0 3}$ & $\mathbf{2 . 9 1}$ \\
$\mathrm{C}_{5}-\mathrm{C}_{9}$ & 1.481 & 5.02 & 1.483 & 5.03 \\
$\mathrm{~S}_{8}-\mathrm{O}$ & 1.466 & 8.42 & 1.460 & 8.74 \\
\hline
\end{tabular}

In order to achieve an experimental support to the theoretical results we have recorded the infrared spectra of both molecules from solid samples. Wavenumbers of the more relevant bands are listed in Table 2. 
Table 2. Wavenumbers and relative intensities of the bands measured in the infrared spectra of pyrazolium sulfonates in the $1700-1100 \mathrm{~cm}^{-1}$ region

\begin{tabular}{|c|c|c|c|c|}
\hline \multicolumn{2}{|c|}{ Pyrazolium-4-sulfonate 18a } & \multicolumn{2}{|c|}{ Pyrazolium-3-sulfonate $\mathbf{1 5 a}$} & \multirow{2}{*}{ Assignments $^{\mathrm{c}}$} \\
\hline $\mathrm{wn}^{\mathrm{a}}$ & rel. int. ${ }^{b}$ & $\mathrm{wn}^{\mathrm{a}}$ & rel. int. ${ }^{b}$ & \\
\hline 1591 & $\mathrm{~W}$ & 1592 & $\mathrm{w}$ & $v(\mathrm{bz})$ \\
\hline 1546 & $\mathrm{~m}$ & 1537 & $\mathrm{~m}$ & $v($ py $)$ \\
\hline 1506 & $\mathrm{~m}-\mathrm{s}$ & 1503 & $\mathrm{~s}$ & $v($ py $)$ \\
\hline 1493 & $\mathrm{~s}$ & 1489 & $\mathrm{~m}-\mathrm{s}$ & $v(\mathrm{py}), \delta\left(\mathrm{CH}_{3}\right)$ \\
\hline 1457 & $\mathrm{w}$ & 1457 & $\mathrm{~m}$ & $v(\mathrm{py}), \delta\left(\mathrm{CH}_{3}\right)$ \\
\hline 1439 & $\mathrm{w}$ & 1446 & $\mathrm{~W}$ & $\delta\left(\mathrm{CH}_{3}\right)$ \\
\hline 1415 & $\mathrm{~m}$ & 1423 & $\mathrm{~m}$ & $\delta\left(\mathrm{CH}_{3}\right)$ \\
\hline 1391 & $\mathrm{~m}$ & 1411 & $\mathrm{~m}$ & $\delta\left(\mathrm{CH}_{3}\right)$ \\
\hline 1334 & $\mathrm{~W}$ & 1287 & $\mathrm{~W}$ & $v(\mathrm{~N}-\mathrm{N})$ \\
\hline 1234 & vs & 1261 & vs & $\delta\left(\mathrm{SO}_{3}^{-}\right)$ \\
\hline 1222 & vs & 1239 & vs & $\delta\left(\mathrm{SO}_{3}{ }^{-}\right)$ \\
\hline 1159 & $\mathrm{~s}$ & 1159 & $\mathrm{w}-\mathrm{m}$ & $\delta(\mathrm{C}-\mathrm{H})_{\mathrm{py}}, \mathrm{r}\left(\mathrm{CH}_{3}\right)$ \\
\hline 1096 & $\mathrm{~m}-\mathrm{s}$ & 1097 & $\mathrm{~s}$ & $v($ union bond $), \delta(\mathrm{C}-\mathrm{H})_{\mathrm{py}}$ \\
\hline 1074 & $\mathrm{w}$ & 1074 & $\mathrm{w}$ & $\delta(\mathrm{C}-\mathrm{H})_{\mathrm{bz}}$ \\
\hline 1032 & $\mathrm{~s}$ & 1040 & $\mathrm{~s}$ & $\delta(\mathrm{C}-\mathrm{H})_{\mathrm{py}}, \mathrm{r}\left(\mathrm{CH}_{3}\right)$ \\
\hline 1025 & $\mathrm{~m}$ & 1017 & $\mathrm{w}-\mathrm{m}$ & $\mathrm{r}\left(\mathrm{CH}_{3}\right)$ \\
\hline
\end{tabular}

${ }^{\mathrm{a}}$ Wavenumbers in $\mathrm{cm}^{-1} \cdot{ }^{\mathrm{b}} \mathrm{s}=$ strong, $\mathrm{m}=$ medium, $\mathrm{w}=$ weak, $\mathrm{v}=$ very. ${ }^{\mathrm{c}} v=$ stretching, $\delta=$ bending, $r=$ methyl rocking; $b z=$ benzene; $p y=$ pyrazolium

The most outstanding result is the opposite behaviour recorded for the bands of aromatic and sulfonate moieties. Most of the bands assigned to stretching vibrations of benzene and pyrazolium rings upshift when going from 3-sulfonate (PCCMB) to 4-sulfonate (CCMB). This is an interesting result as, in spite of the positive charge of the pyrazolium ring is smaller in the PCCMB, the electronic density in the CCMB is more effectively localized over the inter-atomic regions, giving as a consequence stronger skeletal bonds. On the contrary, the two $\mathrm{SO}_{3}$ stretching bands of 3-sulfonate, which were clearly assignable to the infrared bands at 1261 and $1239 \mathrm{~cm}^{-1}$, are measured at 1234 and $1222 \mathrm{~cm}^{-1}$ in 4-sulfonate, as accurately predicted by the calculated force constants (Table 1). Strong infrared bands are related with the stretching vibration of the union bond, namely at 1097 and $1096 \mathrm{~cm}^{-1}$ for 3- and 4-sulfonate, respectively. Although this deviation is in agreement with the force constants, it is too small to fully describe the different strength between the two bonds, which indicates that other vibrational coordinates contribute to the corresponding normal mode. 


\section{Experimental Section}

General. Flash-chromatography was performed with silica gel $60(0.040-0.063 \mathrm{~mm})$. Nuclear magnetic resonance (NMR) spectra were obtained with a Bruker Avance 400 NMR spectrometer. ${ }^{1} \mathrm{H}$ NMR spectra were recorded at $400 \mathrm{MHz}$ and ${ }^{13} \mathrm{C}$ NMR spectra at $100 \mathrm{MHz}$, with the solvent peak or tetramethylsilane used as the internal reference. Multiplicities are described by using the following abbreviations: $\mathrm{s}=$ singlet, $\mathrm{d}=$ doublet, $\mathrm{t}=$ triplet, $\mathrm{q}=$ quartet, sept $=$ septet and $\mathrm{m}=$ multiplet. FT-IR spectra of all compounds except for 15a and 18a were obtained on a Bruker Vector 22 in the range of 400 to $4000 \mathrm{~cm}^{-1}$. All substances were measured as pellets $(2.5 \%)$ in $\mathrm{KBr}$. Infrared spectra of $\mathbf{1 5 a}$ and $\mathbf{1 8 a}$ at room temperature were recorded from pure solid samples, dispersed into a $\mathrm{KBr}$ pellet, using a Bruker VERTEX 70 Fouriertransform (FT) spectrometer purged with dry nitrogen. The $\mathrm{KBr}$ used was dried following the usual routine for infrared measurements $\left(110^{\circ} \mathrm{C}\right.$, at least $\left.24 \mathrm{~h}\right)$. Typically, 500 scans at a resolution better than $4 \mathrm{~cm}^{-1}$ were accumulated to optimize the signal-to-noise ratio. Individual scans were examined by the recording routine before averaging, being automatically discarded when the mean intensity deviations were greater than $10 \%$ over the full interferogram length. The mass spectra were measured with a Varian 320 MS Triple Quad GC/MS/MS with a Varian 450GC. The ESI mass spectra were measured with an Agilent LCMSD Series HP1100 with APIES. Samples were sprayed from methanol. Melting points are uncorrected and were determined in an apparatus according to Dr. Tottoli (Büchi). All yields are isolated yields. They are not optimized. The Gaussian'09 package of programs ${ }^{45}$ was used for DFT quantum chemical calculations. The Becke's three parameter (B3) gradient-corrected exchange functional was used, and the nonlocal correlation was provided by the Perdew-Wang'91 (PW91) expressions. ${ }^{46,47}$ To simulate a polar environment, a polarizable continuum model (PCM) was employed. ${ }^{48,49}$ This model places the solute molecule into a size-adapted cavity formed from overlapping atom-centered van der Waals spheres, while the solvent is assimilated to a continuum characterized by its dielectric constant (78.4 for water). Ground state electronic properties and vibrational features were obtained using the split-valence $6-311+\mathrm{G}(2 \mathrm{~d}, \mathrm{p})$ basis set. ${ }^{50,51}$ It includes diffuse functions on heavy atoms and polarization on all the atoms, which allows for a suitable description of molecules with charge separation as zwitterions or betaines. The minimum energy structures were achieved by permitting all the geometrical parameters to vary independently, Harmonic force constants, in Cartesian coordinates, were evaluated at the ground state optimized geometry using analytical second derivatives. The Cartesian force constants were transformed into a set of non-redundant locally symmetrized internal coordinates accordingly to the Pulay methodology. ${ }^{52}$ An X-ray crystallographic analysis of $\mathrm{C}_{12} \mathrm{H}_{14} \mathrm{Cl}_{2} \mathrm{~N}_{2} \mathrm{O}_{4} \mathrm{~S}$ was performed at $223(2) \mathrm{K}$ by using a STOE IPDS II diffractometer with Mo-K $\mathrm{K}_{\alpha}$ radiation $(\lambda=0.71073 \AA)$ and a graphite monochromator. Crystal system: triclinic, SG P1 (No. 2), $Z=2$, a $=781.0(4) \mathrm{pm}, \mathrm{b}=833.0$ (3) $\mathrm{pm}, \mathrm{c}=1299.5(4) \mathrm{pm}, \alpha=94.97(3)^{\circ}, \beta=94.66(3)^{\circ}, \gamma=114.94(3)^{\circ}, \mathrm{V}_{\mathrm{EZ}}=757.2(5) \cdot 10^{6} \mathrm{pm}^{3}$. The crystal structures were dissolved by direct methods using SHELXS- $97^{53}$ and refined using alternating cycles of least squares refinements against $\mathrm{F}^{2}$ (SHELXL-97) ${ }^{53}$. All non $\mathrm{H}$ atoms were 
found in difference Fourier maps and were refined with anisotropic displacement parameters. The $\mathrm{H}$ positions were determined by final difference Fourier syntheses. The refinement converged to a final $\mathrm{wR} 2=0.0770$ and $\mathrm{R} 1=0.0424$ for 2656 unique reflections and 246 refined parameters with a goodness-of-fit of 1.053. Further details of the crystal structure investigations have been deposited with the Cambridge Crystallographic Data Centre, CCDC 827948. Copies of this information may be obtained free of charge on application to CCDC, 12 Union Road, Cambridge, CB2 1EZ, UK (Fax: +44(1223)-336 033; e-mail: fileserv@ccdc.ac.uk or http://www.ccdc.cam.ac.uk).

1-(3,5-dichlorophenyl)-2,5-dimethylpyrazole-3-thione (14b). A sample of $183 \mathrm{mg}(0.643$ mmol) of 1-(3,5-dichlorophenyl)-2,5-dimethylpyrazolium-3-carboxylate ${ }^{6}$ was mixed with $82 \mathrm{mg}$ of sulfur, suspended in $2 \mathrm{~mL}$ of toluene, and heated at reflux temperature for $3 \mathrm{~h}$. After removing the solvent in vacuo, the residue was chromatographed with $\mathrm{MeOH}$ to give $107 \mathrm{mg}(61 \%)$ of the product, mp: $180-181{ }^{\circ} \mathrm{C} .{ }^{1} \mathrm{H}$ NMR $\left(400 \mathrm{MHz}, 21^{\circ} \mathrm{C}, \mathrm{CDCl}_{3}\right.$, TMS): $\delta=7.58(\mathrm{t}, 1 \mathrm{H}, H \mathrm{Ph}, J=$ $1.4 \mathrm{~Hz}$ ), 7.19 (d, $2 \mathrm{H}, H \mathrm{Ph}, J=1.4 \mathrm{~Hz}), 6.28$ (s, $1 \mathrm{H}, 4-H), 3.60$ (s, $\left.3 \mathrm{H}, 2-\mathrm{CH}_{3}\right), 2.08$ (s, $3 \mathrm{H}, 5-$ $\left.\mathrm{CH}_{3}\right)$ ppm. ${ }^{13} \mathrm{C} \mathrm{NMR}\left(100 \mathrm{MHz}, 2{ }^{\circ} \mathrm{C}, \mathrm{CDCl}_{3}\right.$, TMS $): \delta=173.6,146.9,136.9,136.6,131.1$, 126.3, 113.8, 33.9, 12.2 ppm. MS: $272.1\left[\mathrm{M}^{+}\right]$(50\%). IR (KBr): 3445, 2999, 2360, 1572, 1550, 1438, 1347, 1210, 1150, 1118, 1051, 856, 806, 680, $594 \mathrm{~cm}^{-1}$. Anal. Calcd for $\mathrm{C}_{11} \mathrm{H}_{10} \mathrm{~N}_{2} \mathrm{SCl}_{2}$ : C 48.36, H 3.69; N 10.25. Found: C 47.79; H 3.48; N 10.30.

2,5-dimethyl-1-phenylpyrazolium-3-sulfonate (15a). An aqueous solution of $197 \mathrm{mg}(0.965$ mmol) of 2,5-dimethyl-1-phenylpyrazole-3-thione ${ }^{6}$ was treated with chlorine over a period of 2 $\mathrm{h}$. Then, the solution was concentrated in vacuo. The resulting precipitate was filtered off. Yield: $123 \mathrm{mg}(51 \%), \mathrm{mp}: 302-304{ }^{\circ} \mathrm{C} .{ }^{1} \mathrm{H}$ NMR (400 MHz, $21{ }^{\circ} \mathrm{C}$, DMSO- $\left.d_{6}\right): \delta=7.72-7.83$ (m, 5 $\mathrm{H}, H \mathrm{Ph}), 6.96(\mathrm{~s}, 1 \mathrm{H}, 4-H), 3.83\left(\mathrm{~s}, 3 \mathrm{H}, 2-\mathrm{CH}_{3}\right), 2.20\left(\mathrm{~s}, 3 \mathrm{H}, 5-\mathrm{CH}_{3}\right) \mathrm{ppm} .{ }^{13} \mathrm{C} \mathrm{NMR}(100$ $\mathrm{MHz}, 21^{\circ} \mathrm{C}$, DMSO- $\left.d_{6}\right): \delta=151.9,146.8,132.5,130.6,130.5,129.0,106.9,35.8,12.0 \mathrm{ppm}$. HRESIMS calcd. for $\mathrm{C}_{11} \mathrm{H}_{13} \mathrm{~N}_{2} \mathrm{O}_{3} \mathrm{~S}$ [M+H'] 253.0647 . Found: 253.0646 .

1-(3,5-dichlorophenyl)-2,5-dimethylpyrazolium-3-sulfonate (15b). An aqueous solution of 52 $\mathrm{mg}(0.19 \mathrm{mmol})$ of 1-(3,5-dichlorophenyl)-2,5-dimethylpyrazole-3-thione was treated with chlorine over a period of $2 \mathrm{~h}$. Then, the solution was concentrated in vacuo and the resulting precipitate was filtered off. Yield: $49 \mathrm{mg}(80 \%)$, mp: dec. $367-368{ }^{\circ} \mathrm{C}$. ${ }^{1} \mathrm{H} \mathrm{NMR}(400 \mathrm{MHz}$, $\left.21^{\circ} \mathrm{C}, \mathrm{DMSO}-d_{6}\right): \delta=8.11-8.12(\mathrm{~m}, 3 \mathrm{H}, H \mathrm{Ph}), 6.96(\mathrm{~s}, 1 \mathrm{H}, 4-H), 3.89$ (s, $\left.3 \mathrm{H}, 2-\mathrm{CH}_{3}\right), 2.24$ (s, $\left.3 \mathrm{H}, 5-\mathrm{CH}_{3}\right) \mathrm{ppm} .{ }^{13} \mathrm{C} \mathrm{NMR}\left(100 \mathrm{MHz}, 2{ }^{\circ} \mathrm{C}\right.$, DMSO- $\left.d_{6}\right): \delta=152.3,147.4,135.4,132.6,132.2$, 128.6, 107.1, 36.0, 11.9 ppm. IR (KBr): 3065, 1576, 1442, 1242, 1101, 1042, 872, 810, 683, 653, $535 \mathrm{~cm}^{-1}$. HRESIMS calcd. for $\mathrm{C}_{11} \mathrm{H}_{11} \mathrm{~N}_{2} \mathrm{O}_{3} \mathrm{SCl}_{2}\left[\mathrm{M}+\mathrm{H}^{+}\right]$: 320.9867 . Found: 320.9864.

5-Methyl-1-phenylpyrazole-4-sulfonic acid (17). A sample of $475 \mathrm{mg}$ (3.0 mmol) of 5-methyl1-phenylpyrazole ${ }^{54}$ was first dissolved in $2 \mathrm{~mL}$ of anhydrous $\mathrm{CHCl}_{3}$ and then treated with $0.4 \mathrm{~mL}$ $(6.0 \mathrm{mmol})$ of chlorosulfonic acid. The resulting mixture was then heated at reflux temperature over a period of $2 \mathrm{~h}$. After cooling, the mixture was concentrated in vacuo and poured on $100 \mathrm{~mL}$ of ice. After neutralization with aqueous $\mathrm{NaOH}$, the solution was evaporated to dryness in vacuo. The resulting residue was extracted with $120 \mathrm{~mL}$ of EtOH and filtered over a small column. 
After distilling off the EtOH, $710 \mathrm{mg}(99 \%)$ of the title compound were isolated, mp: $256-257$ ${ }^{\circ} \mathrm{C} .{ }^{1} \mathrm{H}$ NMR $\left(400 \mathrm{MHz}, 21^{\circ} \mathrm{C}, \mathrm{D}_{2} \mathrm{O}\right): \delta=7.79$ (s, $\left.1 \mathrm{H}, 3-H\right)$, 7.37-7.38 (m, $3 \mathrm{H}, \mathrm{HPh}$ ), 7.21-7.23 $(\mathrm{m}, 2 \mathrm{H}, \mathrm{HPh}), 2.21\left(\mathrm{~s}, 3 \mathrm{H}, 5-\mathrm{CH}_{3}\right) \mathrm{ppm} .{ }^{13} \mathrm{C} \mathrm{NMR}\left(100 \mathrm{MHz}, 21^{\circ} \mathrm{C}, \mathrm{D}_{2} \mathrm{O}\right): \delta=140.6,137.6$, 137.0, 129.5, 129.4, 125.6, 123.5, 10.1 ppm. MS: 158.1 [ $\left.\mathrm{M}^{+}-\mathrm{SO}_{3}\right]$ (100\%). IR (KBr): 3085, 2644, 1558, 1527, 1494, 1456, 1396, 1287, 1245, 1194, 1102, 1024, 926, 771, 686, 634, 578544 $\mathrm{cm}^{-1}$. Anal. Calcd for $\mathrm{C}_{10} \mathrm{H}_{10} \mathrm{~N}_{2} \mathrm{O}_{3} \mathrm{~S} \cdot 0.75 \mathrm{H}_{2} \mathrm{O}: \mathrm{C}$ 47.70, H 4.60; N 11.13. Found: $\mathrm{C} 47.73 ; \mathrm{H}$ $3.83 ;$ N 11.16 .

\section{2,5-dimethyl-1-phenylpyrazolium-4-sulfonate (18a)}

Method A. A sample of $357 \mathrm{mg}$ (1.5 mmol) of 5-methyl-1-phenylpyrazol-4-sulfonic acid 17 was dissolved in $5 \mathrm{~mL}$ of xylene, then, $0.28 \mathrm{~mL}(3.0 \mathrm{mmol})$ of dimethylsulfate was added. The mixture was heated at reflux temperature for $2 \mathrm{~h}$. After evaporation to dryness in vacuo, $5 \mathrm{~mL}$ of $18 \% \mathrm{H}_{2} \mathrm{SO}_{4}$ was added and the mixture was heated at $100^{\circ} \mathrm{C}$ for $5 \mathrm{~h}$. After neutralization with aqueous $\mathrm{NaOH}$, the solvent was removed by distillation and the residue was extracted with 150 $\mathrm{mL}$ of ethanol. After evaporation to dryness, the residue was recrystallized from $\mathrm{MeOH}$. Yield: $172 \mathrm{mg}(46 \%)$.

Method B. A sample of $158 \mathrm{mg}(1.0 \mathrm{mmol})$ of 5-methyl-1-phenylpyrazole ${ }^{54}$ was dissolved in 1 $\mathrm{mL}$ of xylene. Then, $0.95 \mathrm{~mL}(10.0 \mathrm{mmol})$ of dimethylsulfate was added. The mixture was heated over a period of $2 \mathrm{~h}$, cooled and concentrated in vacuo. The resulting residue was dissolved in hot $\mathrm{MeOH} /$ EtOAc (1:1). On cooling, a precipitae formed which was filtered off. Yield: $103 \mathrm{mg}(41 \%)$.

Method C. A sample of $207 \mathrm{mg}(0.73 \mathrm{mmol})$ of 2,5-dimethyl-1-phenylpyrazolium methylsulfat was dissolved in $1 \mathrm{~mL}$ of concentrated sulfuric acid and stirred at $140{ }^{\circ} \mathrm{C}$. After cooling, the mixture was poured on ice, neutralized with $\mathrm{NaOH}$, and evaporated to dryness. The resulting residue was then extracted with $120 \mathrm{~mL}$ of $\mathrm{MeOH}$, and filtered through a short column. Recrystallisation from MeOH / EtOAC (1:1). Yield: $32 \mathrm{mg}(17 \%)$, dec. $324-328{ }^{\circ} \mathrm{C} ;{ }^{1} \mathrm{H} \mathrm{NMR}$ (400 MHz, $21^{\circ} \mathrm{C}$, DMSO-d $): \delta=8.77(\mathrm{~s}, 1 \mathrm{H}, 3-H), 7.72-7.79(\mathrm{~m}, 5 \mathrm{H}, H \mathrm{Ph}), 3.71(\mathrm{~s}, 3 \mathrm{H}, 2-$ $\left.\mathrm{CH}_{3}\right), 2.30$ (s, $\left.3 \mathrm{H}, 5-\mathrm{CH}_{3}\right) \mathrm{ppm} .{ }^{13} \mathrm{C} \mathrm{NMR}\left(100 \mathrm{MHz}, 21^{\circ} \mathrm{C}, \mathrm{DMSO}-d_{6}\right): \delta=144.5,136.0,132.5$, 130.6, 130.4, 129.0, 128.8, 37.2, 10.9 ppm. ESIMS: $275.0\left(\mathrm{M}+\mathrm{Na}^{+}, 85 \%\right), 527.1\left(2 \mathrm{M}+\mathrm{Na}^{+}\right.$, $100 \%)$. HRESIMS calcd. for $\mathrm{C}_{11} \mathrm{H}_{13} \mathrm{~N}_{2} \mathrm{O}_{3} \mathrm{~S}\left[\mathrm{M}+\mathrm{H}^{+}\right]$: 253.0647. Found: 253.0640 .

2,3,5-Trimethyl-1-phenylpyrazolium-4-sulfonate (18b). A sample of $344 \mathrm{mg}(2.0 \mathrm{mmol})$ of 3,5-dimethyl-1-phenylpyrazole ${ }^{55}$ was dissolved in $10 \mathrm{~mL}$ of xylene and then treated with $0.38 \mathrm{ml}$ $(4.0 \mathrm{mmol})$ of dimethylsulfate. The mixture was heated at reflux temperature over a period of 2 $\mathrm{h}$, cooled, and concentrated in vacuo. The resulting precipitate was recrystallized from $\mathrm{MeOH} /$ EtOAC (1:1). Yield: $65 \mathrm{mg}(19 \%)$, dec. $344-345{ }^{\circ} \mathrm{C} .{ }^{1} \mathrm{H}$ NMR (400 MHz, $\left.21^{\circ} \mathrm{C}, \mathrm{DMSO}-d_{6}\right): \delta$ $=7.70-7.78(\mathrm{~m}, 5 \mathrm{H}, H \mathrm{Ph}), 3.57\left(\mathrm{~s}, 3 \mathrm{H}, 2-\mathrm{CH}_{3}\right), 2.64\left(\mathrm{~s}, 3 \mathrm{H}, 3-\mathrm{CH}_{3}\right), 2.30\left(\mathrm{~s}, 3 \mathrm{H}, 5-\mathrm{CH}_{3}\right) \mathrm{ppm}$.

${ }^{13} \mathrm{C}$ NMR (100 MHz, $21{ }^{\circ} \mathrm{C}$, DMSO- $\left.d_{6}\right): \delta=144.7,143.7,132.4,130.9,130.5,129.0,126.6$, 34.4, 11.3, 10.8 ppm. IR (KBr): 1490, 1421, 1230, 1170, 1114, 1034, 782, 747, 703, 660, 622, $544 \mathrm{~cm}^{-1}$. HRESIMS calcd. for $\mathrm{C}_{12} \mathrm{H}_{14} \mathrm{~N}_{2} \mathrm{O}_{3} \mathrm{SNa}\left[\mathrm{M}+\mathrm{Na}^{+}\right]$: 289.0623. Found: 289.0623 . 
2-Ethyl-5-methyl-1-phenylpyrazolium-4-sulfonate (18c). A sample of $316 \mathrm{mg}$ (2.0 mmol) of 1-phenyl-5-methylpyrazole ${ }^{54}$ was dissolved in $2 \mathrm{~mL}$ of xylene and then treated with $0.53 \mathrm{~mL}$ (4.0 mmol) of diethylsulfate. The mixture was then heated at reflux temperature for $2 \mathrm{~h}$, cooled, and concentrated in vacuo. The resulting precipitate was filtered off and recrystallized from $\mathrm{MeOH} /$ EtOAc. Yield: $77 \mathrm{mg}$ (14\%), mp: dec. $293-295{ }^{\circ} \mathrm{C} .{ }^{1} \mathrm{H}$ NMR $\left(400 \mathrm{MHz}, 21^{\circ} \mathrm{C}, \mathrm{D}_{2} \mathrm{O}\right): \delta=8.70$ (s, $1 \mathrm{H}, 3-H), 7.75-7.85(\mathrm{~m}, 3 \mathrm{H}, H \mathrm{Ph}), 7.61-7.64(\mathrm{~m}, 2 \mathrm{H}, H \mathrm{Ph}), 4.18\left(\mathrm{q}, 2 \mathrm{H}, 2-\mathrm{CH}_{2} \mathrm{CH}_{3}, J=8.0\right.$ $\mathrm{Hz}), 2.42\left(\mathrm{~s}, 3 \mathrm{H}, 5-\mathrm{CH}_{3}\right), 1.38\left(\mathrm{t}, 3 \mathrm{H}, 2-\mathrm{CH}_{2} \mathrm{CH}_{3}, J=8.0 \mathrm{~Hz}\right) \mathrm{ppm} .{ }^{13} \mathrm{C} \mathrm{NMR}\left(100 \mathrm{MHz}, 21^{\circ} \mathrm{C}\right.$, $\left.\mathrm{D}_{2} \mathrm{O}\right): \delta=147.1,134.8,133.2,130.8,129.9,128.4,125.2,46.8,13.1,10.7$ ppm. IR (KBr): 3117 , $1491,1391,1242,1215,1169,1123,1031,904,789,758,705,652,544 \mathrm{~cm}^{-1}$.

HRESIMS calcd. for $\mathrm{C}_{12} \mathrm{H}_{14} \mathrm{~N}_{2} \mathrm{O}_{3} \mathrm{SNa}\left[\mathrm{M}+\mathrm{Na}^{+}\right.$]: 289.0623. Found: 289.0622 .

1-(3,5-dichlorophenyl)-2,5-dimethylpyrazolium-4-sulfonate (18d). A sample of $100 \mathrm{mg}(0.31$ mmol) of 1-(3,5-dichlorophenyl)-5-methylpyrazole ${ }^{6}$ was dissolved in $1.2 \mathrm{~mL}$ of xylene. Then, $0.05 \mathrm{~mL}(0.53 \mathrm{mmol})$ of dimethylsulfate was added. The mixture was heated over a period of 2.5 $\mathrm{h}$, cooled and concentrated in vacuo. The resulting residue was dissolved in hot $\mathrm{MeOH} / \mathrm{EtOAc}$ (1:1). On cooling, a precipitate formed, which was filtered off. Yield: $30 \mathrm{mg}$ (20\%), dec. 339 $340{ }^{\circ} \mathrm{C} .{ }^{1} \mathrm{H}$ NMR $\left(400 \mathrm{MHz}, 21^{\circ} \mathrm{C}\right.$, DMSO-d $): \delta=8.81(\mathrm{~s}, 1 \mathrm{H}, 3-H), 8.12(\mathrm{t}, 1 \mathrm{H}, H \mathrm{Ar}, J=1.9$ $\mathrm{Hz}), 8.06$ (d, $2 \mathrm{H}, H \mathrm{Ar}, J=1.9 \mathrm{~Hz}), 3.77\left(\mathrm{~s}, 3 \mathrm{H}, 2-\mathrm{CH}_{3}\right), 2.35$ (s, 3H, 5-CH3) ppm. ${ }^{13} \mathrm{C}$ NMR $\left(100 \mathrm{MHz}, 21^{\circ} \mathrm{C}\right.$, DMSO- $\left.d_{6}\right): \delta=145.1,136.7,135.4,132.6,132.2,129.2,128.4,37.3,10.8$ ppm. IR (KBr): 3124, 3064, 1631, 1577, 1509, 1441, 1406, 1234, 1225, 1209, 1165, 1117, 1066, 1033, 808, 658, $647 \mathrm{~cm}^{-1}$. HRESIMS: Calcd for $\mathrm{C}_{11} \mathrm{H}_{11} \mathrm{Cl}_{2} \mathrm{~N}_{2} \mathrm{O}_{3} \mathrm{~S}$ : 320.9867. Found: 320.9863.

\section{Acknowledgements}

Dr. Gerald Dräger, University of Hannover (Germany) is gratefully acknowledged for measuring the high resolution mass spectra.

\section{References}

1. (a) Hahn, F. E.; Jahnke, M. C. Angew. Chem. 2008, 120, 3166; Angew. Chem. Int. Ed. 2008, 47, 3122. (b) N-Heterocyclic Carbenes in Synthesis Nolan, S. P., Ed., Wiley-VCH: Weinheim 2006. (c) Glorius, F. A. Top. Organomet. Chem. 2007, 21, 1. (d) Crudden, C. M.; Allen, D. P. Coord. Chem. Rev. 2004, 248, 2247 (e) Herrmann, W. A. Angew. Chem. 2002, 114, 1342; Angew. Chem. Int. Ed. 2002, 41, 1290;. (f) Weskamp, T.; Böhm, V. P. W.; Herrmann, W. A. J. Organomet. Chem. 2000, 600, 12. (g) Bourissou, D.; Guerret, O.; Gabbaï, F.; Bertrand, G. Chem. Rev. 2000, 100, 39.

2. Albrecht, M. Chem. Commun. 2008, 3601.

3. (a) Köcher, C.; Herrmann, W. A. J. Organomet. Chem. 1997, 532, 261. (b) Herrmann, W. A.; Schütz, J.; Frey, G. D.; Herdtweck, E. Organometallics 2006, 25, 2437. (c) Prades, A.; 
Corberán, R.; Poyatos, M.; Peris, E. Chem. Eur. J. 2008, 14, 11474. (d) Prades, A.; Viciano, M.; Sanaú, M.; Peris, E. Organometallics 2008, 27, 4254. (e) Schütz, J.; Herdtweck, E.; Herrmann, W. A. Organometallics 2004, 23, 6084.

4. Schmidt, A.; Habeck, T. Lett. Org. Chem. 2005, 2, 37.

5. Schmidt, A.; Habeck, T.; Merkel, L.; Mäkinen, M.; Vainiotalo, P. Rapid Comm. Mass Spectrom. 2005, 19, 2211.

6. (a) Schmidt, A.; Münster, N.; Dreger, A. Angew. Chem. 2010, 122, 2851; Angew. Chem. Int. Ed. 2010, 49, 2790. (b) Dreger, A.; Cisneros Camuña, R.; Münster, N.; Rokob, T. A.; Pápai, I.; Schmidt, A. Eur. J. Org. Chem. 2010, 4296.

7. (a) Schneider, S. K.; Roembke, P.; Julius, G. R.; Loschen, C.; Raubenheimer, H. G.; Frenking, G.; Herrmann, W. A. Eur. J. Inorg. Chem. 2005, 2973. (b) Han, Y.; Huynh, H. V.; Tan, G. K. Organometallics 2007, 26, 6581.

8. Lavallo, V.; Dyker, C. A.; Donnadieu, B.; Bertrand, G. Angew. Chem. 2008, 120, 5491; Angew. Chem. Int. Ed. 2008, 47, 5411.

9. Christl, M.; Engels, B. Angew. Chem. 2009, 121, 1566; Angew. Chem. Int. Ed. 2009, 48, 1538 .

10. (a) Lavallo, V.; Dyker, C. A.; Donnadieu, B.; Bertrand, G. Angew. Chem. 2009, 121, 1568; Angew. Chem. Int. Ed. 2009, 48, 1540. (b) Fernández, I.; Dyker, C. A.; DeHope, A.; Donnadieu, B.; Frenking, G.; Bertrand, G. J. Am. Chem. Soc. 2009, 131, 11875.

11. (a) Ollis, W. D.; Ramsden, C. A.; Stanforth, S. P. Tetrahedron 1985, 41, 2239. (b) Schmidt, A. Curr. Org. Chem. 2004, 8, 653. (c) Schmidt, A. Adv. Heterocycl. Chem. 2003, 85, 67. (d) Schmidt, A.; Habeck, T.; Lindner, A. S.; Snovydovych, B.; Namyslo, J. C.; Adam, A.; Gjikaj, M. J. Org. Chem. 2007, 72, 2236. (e) Schmidt, A.; Mordhorst, T. ARKIVOC 2003, (xiv), 233.

12. (a) Schmidt, A.; Snovydovych, B.; Synthesis 2008, 2798. (b) Schmidt, A.; Snovydovych, B.; Hemmen, S. Eur. J. Org. Chem. 2008, 4313. (c) Schmidt, A.; Snovydovych, B.; Habeck, T.; Dröttboom, P.; Gjikaj, M.; Adam, A. Eur. J. Org. Chem. 2007, 4909. (d) Schmidt, A.; Beutler, A.; Habeck, T.; Mordhorst, T.; Snovydovych, B. Synthesis 2006, 1882.

13. Schmidt, A.; Beutler, A.; Albrecht, M.; Ramírez, F. J. Org. Biomol. Chem. 2008, 6, 287.

14. Walter, W.; Holst, J. J. Mol. Struc. 1971, 9, 413.

15. Ojo, J. F.; Petersen, J. L.; Otoikhian, A.; Simoyi, R. H. Can J. Chem. 2006, 84, 825.

16. Petersen, J. L.; Otoikhian, A. A.; Morakinyo, M. K.; Simoyi, R. H. Can. J. Chem. 2010, 88, 1247.

17. (a) Kuhn, N.; Bohnen, H.; Bläser, D.; Boese, D.; Maulitz, A. H. J. Chem. Soc., Chem. Commun. 1994, 2283. (b) Kuhn, N.; Bohnen, H.; Fahl, J.; Bläser, D.; Boese, R. Chem. Ber. 1996, 129, 1579.

18. Kuhn, N.; Eichele, K.; Walker, M. Z. Anorg. Allg. Chem. 2001, 627, 2565.

19. Kuhn, N.; Eichele, K.; Walker, M.; Berends, T.; Minkwitz, R. Z. Anorg. Allg. Chem. 2002, $628,2026$.

20. El'tsov, A. V.; Lopatin, V. E. Zhurnal Organicheskoi Khimii 1971, 7, 1284; Chem. Abstr. 
75, 98496].

21. Damir, N.A.; Sveshnikov, N. N., SU 19660311 Chem.Abstr. 67,108659.

22. (a) Lehmann, U.; Balli, H. Dyes and Pigments 1983, 4, 121. (b) Gross, W.; Oberkobusch, D.; Benicke, W. GWXXBX DE 102008062236 A1 20091015; Chem. Abstr. 151, 433237.

23. Doerge, D. R.; Decker, C. J.; Takazawa, R. S. Biochemistry 1993, 32, 58.

24. (a) Sureau, R. F. M.; Kremer, G. V. H.; Dupré, V. M. GWXXBX DE 2227950 A 19721228 Chem. Abstr. 78, 99055. (b) Gerbal, C. F. FRXXBL FR 2142783 A1 19730202; Chem. Abstr. 79, 67829.

25. Ehrenschwender, T.; Varga, B. R.; Kele, P.; Wagenknecht, H.-A. Chem. Asian J. 2010, 5, 1761.

26. Katritzky, A. R.; Krepski, Larry R.; Rasmussen, Jerald K.; Heilmann, Steven M.; Tarr, Richard D. Eur. Pat. Appl. (1989), EPXXDW EP 319156 A1 19890607; Chem.Abstr. 111, 215148.

27. Bradshaw, J.; Cook, M. C.; Gregory, G. I.; Beels, C. D. Ger. Offen., 1976, GWXXBX DE 2557397 A1 19760624 ; Chem. Abstr. 86, 55462.

28. Allen, S. D.; Conuel, J. R.; Decker, D. E.; Cherian, A. E. PCT Int. Appl. (2010), PIXXD2 WO 2010033705 A1 20100325; Chem. Abstr. 152, 406316.

29. Tolmachev, A. I.; Kachkovskii, A. D.; Kudinova, M. A.; Kurdiukov, V. V.; Ksenzov, S.; Schrader, S. Dyes and Pigments 2007, 74, 348.

30. Umemoto, T.; Tomizawa, G. J. Org. Chem. 1995, 60, 6563.

31. Jarvis, B. B.; Tong, W. P. Synthesis 1975, 102.

32. Iwamaru, A.; Iwado, E.; Kondo, S.; Newman, R. A.; Vera, B.; Rodríguez, A. D.; Kondo, Y. Mol. Cancer Ther. 2007, 6, 184.

33. Liu, X.; Abbott, N. L. Anal. Chem. 2011, 83, 3033.

34. Skrzypek, L.; Suwinska, K. Heterocycles 2007, 71, 1363.

35. (a) Miyoshi, K. Jpn. Kokai Tokkyo Koho 2008, JP 2008247713; Chem. Abstr. 149, 478935.

(b) Czerney, P.; Wenzel, M.; Schweder, B.; Lehmann, F. US 20040260093; Chem. Abstr. 142, 76184. (c) Czerney, P.; Wenzel, M.; Schweder, B.; Lehmann, F. EPXXDW EP 1318177 A2 20030611; Chem. Abstr. 139 37939. (d) Brabetz, W.; Weber, C. PIXXD2 WO 2010063732 A1 20100610; Chem. Abstr. 153, 54821. (e) Nakamura, T.; Takeuchi, K. JKXXAF JP 2003064083 A 20030305; Chem. Abstr. 138, 206479.

36. Garkusha-Bozhko, V. S.; Ukrain. Khim. Zhur. 1990, 56, 1096; Chem.Abstr. 114, 164098.

37. (a) Schmidt, A. J. Heterocyl. Chem. 2002, 39, 949; (b) Schmidt, A.; Nieger, M. Heterocycles 1999, 51, 2119; (c) Schmidt, A.; Nieger, M. Heterocycles 2001, 55, 827.

38. Schmidt, A.; Habeck, T.; Snovydovych, B.; Eisfeld, W. Org. Lett. 2007, 9, 3515.

39. (a) Schmidt, A.; Rahimi, A. Chem. Comm. 2010, 46, 2995. (b) Rahimi, A.; Schmidt, A. Synthesis 2010, 2621. (c) Rahimi, A.; Schmidt, A. Synlett 2010, 1327.

40. (a) Schmidt, A.; Lindner, A.; Casado Cordon, J.; López Navarrete, J. T.; Ramírez, F. J. Chem. Phys. 2010, 371(1-3), 1. (b) Capel Ferrón, C.; Casado, J.; López Navarrete, J. T.; Dreger, A.; Schmidt, A.; Ramírez, F. J. J. Raman Spectrosc. 2009, 40, 238. (c) Schmidt, A.; 
Snovydovych, B.; Casado, J.; Quirante, J. J.; López Navarrete, J. T.; Ramírez, F. J. Phys. Chem. Chem. Phys. 2009, 11, 341.

41. Michaelis, A.; Mayer, C.; Hahn, W.; Behrens, J. Justus Liebigs Ann. Chem. 1905, 338, 267.

42. Grandberg, I. I.; Nam, N. L. Sorokin, V. I. Chem. Heterocycl. Compd. 1997, 33, 532.

43. (a) Mezei, G.; Raptis, R. G. New. J. Chem. 2003, 27, 1399. (b) Rondestvedt, Jr. C. S.; Chang, P. K. J. Am. Chem. Soc. 1955, 77, 6532.

44. Barry, W. J.; Finar, I. L.; Khatkhate, G. V. J. Chem. Soc. C, 1968, 1120.

45. Gaussian 09, Revision A.1, Frisch, M. J.; Trucks, G. W.; Schlegel, H. B.; Scuseria, G. E.; Robb, M. A.; Cheeseman, J. R.; Scalmani, G.; Barone, V.; Mennucci, B.; Petersson, G. A.; Nakatsuji, H.; Caricato, M.; Li, X.; Hratchian, H. P.; Izmaylov, A. F.; Bloino, J.; Zheng, G.; Sonnenberg, J. L.; Hada, M.; Ehara, M.; Toyota, K.; Fukuda, R.; Hasegawa, J.; Ishida, M.; Nakajima, T.; Honda, Y.; Kitao, O.; Nakai, H.; Vreven, T.; Montgomery, Jr., J. A.; Peralta, J. E.; Ogliaro, F.; Bearpark, M.; Heyd, J. J.; Brothers, E.; Kudin, K. N.; Staroverov, V. N.; Kobayashi, R.; Normand, J.; Raghavachari, K.; Rendell, A.; Burant, J. C.; Iyengar, S. S.; Tomasi, J.; Cossi, M.; Rega, N.; Millam, N. J.; Klene, M.; Knox, J. E.; Cross, J. B.; Bakken, V.; Adamo, C.; Jaramillo, J.; Gomperts, R.; Stratmann, R. E.; Yazyev, O.; Austin, A. J.; Cammi, R.; Pomelli, C.; Ochterski, J. W.; Martin, R. L.; Morokuma, K.; Zakrzewski, V. G.; Voth, G. A.; Salvador, P.; Dannenberg, J. J.; Dapprich, S.; Daniels, A. D.; Farkas, Ö.; Foresman, J. B.; Ortiz, J. V.; Cioslowski, J.; Fox, D. J. Gaussian, Inc., Wallingford CT, 2009.

46. Becke, A. D. J. Chem. Phys. 1993, 98, 5648.

47. Perdew, J. P.; Wang, Y. Phys. Rev. B 1992, 45, 13244.

48. Hriharan, P. C.; Pople, J. A. Theor. Chim. Acta 1973, 28, 213.

49. Clark, T.; Chandrasekhar, J.; Spitznagel, G. W.; Schleyer, P. V. R. J. Comput. Chem. 1983, 4, 294.

50. Miertus, S.; Scrocco, E.; Tomasi, T. Chem. Phys. 1981, 55, 117.

51. Miertus, S.; Tomasi, J. Chem. Phys. 1982, 65, 239.

52. Pulay, P.; Fogarasi, G.; Pang F.; Boggs, J. E. J. Am. Chem. Soc. 1979, 101, 2550.

53. Sheldrick, G. M, SHELXS-97, A program package for crystal structure solution and refinement. University of Göttingen, Germany 1997.

54. Pavlik, J. W.; Connors, R. E.; Burns, D. S.; Kurzweil, E. M. J. Am. Chem. Soc. 1993, 115, 1645.

55. Reddy, C. S.; Devi, M. V.; Sunitha, M.; Nagaraj, A. Chem. Pharm. Bull. 2010, 58, 1622. 